\title{
Pengaruh Komunikasi dan Lingkungan Kerja Terhadap Semangat Kerja Guru SMK Swasta Rokita Sari di Yayasan Perguruan Rokita Sari Bangun Purba
}

\author{
Rosniwaty Bangun ${ }^{1}$, Khamo Waruwu ${ }^{2}$, Putri Paramita ${ }^{3}$ \\ 1,2,3 Universitas Tjut Nyak Dhien, Indonesia \\ sizhukuputri@gmail.com
}

\begin{abstract}
Abstrak : Secara teori komunikasi mempengaruhi semangat kerja seseorang, demikian juga halnya lingkungan dimana seseorang bekerja akan mempengaruhi kinerjanya. Teori tersebut ingin dibuktikan peneliti di sekolah SMK Yayasan Perguruan Rokita Sari Bangun Purba. Sampelnya adalah seluruh guru yang ada di SMK tersebut dan analisis regresi linier berganda digunakan untuk mengetahui pengaruh antara variabel bebas dan terikat. Diperoleh komunikasi berpengaruh positif dan signifikan terhadap semangat kerja (sig yang bernilai $0.000<0.05$ ), lingkungan kerja berpengaruh positif dan signfikan terhadap semangat (nilai sig $0.001<0.05$ ), dan secara simultan komunikasi dan lingkungan kerja berpengaruh positif dan signifikan terhadap semangat kerja pada guru SMK Swasta Rokita Sari (nilai signifikansi $0.000<0.05$ )
\end{abstract}

Kata kunci: komunikasi, Llingkungan kerja, Semangat kerja

\begin{abstract}
In theory, communication affects a person's morale, as well as the environment in which a person works will affect his performance. Researchers want to prove this theory at the Vocational School of the Rokita Sari Bangun Purba Foundation Vocational School. The sample is all teachers in the SMK and multiple linear regression analysis is used to determine the effect of the independent and dependent variables. It was found that communication had a positive and significant effect on morale (sig value $0.000<0.05$ ), the work environment had a positive and significant effect on morale (sig value $0.001<0.05$ ), and simultaneously communication and work environment had a positive and significant effect on teacher morale. Rokita Sari Private Vocational School (significance value 0.000 $<0.05)$
\end{abstract}

Keyword : communication, work environment, morale

Copyright (c) 2021 The Authors. This is an open access article under the CC BY-SA 4.0 license (https://creativecommons.org/licenses/by-sa/4.0/)

\section{PENDAHULUAN}

Banyak pendapat yang sering di dengar bahwa sumber daya manusia merupakan aset bagi organisasi. Dikarenakan pada hakekatnya sumber daya manusia yang menjalankan secara langsung aktivitas dan ujungnya menentukan perkembangan organisasi. Arti pentingnya sumber daya manusia terlihat pada kemampuannya untuk bekerja secara kreatif dan positif dalam melaksanakan suatu kegiatan serta kemampuan 
yang dimiliki untuk mencapai tujuan atau visi dan misi sebuah perusahaan. Visi dan misi organisasi atau perusahaan tidak akan terlaksana dengan baik jika tidak disokong oleh sumber daya manusa. Demikian juga halnya sekolah guru merupakan hal yang sangat penting sebagai penggerak terjadinya proses pendidikan sebagai mana tujuan sekolah.

Untuk menunjang setiap guru memberikan potensi mengajar pada tingkat tertinggi dan menciptakan solusi proses pendidikan yang teratur, maka guru-guru harus memiliki semangat kerja yang tinggi. Perasaan sejahtera bukan hanya dari sisi materi tetapi juga dari sisi hubungan yang baik di sekolah dengan sesama rekan guru dan juga lingkungan yang nyaman dapat menciptakan semangat (Pratama \& Wardani, 2018). Semangat guru-guru dapat dilihat dari bagaimana ia menyukai dan mencintai pekerjaannya dan melakukan pekerjaan secara lebih giat dan sukarela sehingga apapun pekerjaan yang diberikan akan dikerjakan lebih cepat dan sesuai dengan yang diharapkan (Adha et al., 2019). Semangat kerja yang tinggi dipengaruhi oleh banyak faktor diantaranya adalah faktor komunikasi dan lingkungan (Siregar, 2019).

Komunikasi merupakan suatu aktivitas menyampaikan informasi ataupun arahan pemberi informasi kepada orang lain. Kumunikasi haruslah benar-benar efektif, hubungan yang seia sekata, dan kerjasama antara atasan dengan bawahan atau satu rekan kerja akan terlaksana dengan baik dan para pegawai akan selalu bersemangat (Ningrum, 2013). Kepala sekolah sebagai komunikator harus tahu bagaimana menempatkan kalimat sehingga penerima pesan paham apa yang disampaikan baik dengan komunikasi secara langsung maupun memakai media (R. Saleh et al., 2016).

Lingkungan kerja tidak dapat dipisahkan dari salah satu pemberi semangat kerja seseorang, apapun bidang pekerjaan itu. Dengan adanya kondisi lingkungan yang nyaman serta memadai membuat para pegawai menjadi betah dan dapat membangkitkan semangat kerjanya, sebaliknya jika lingkungan kerja yang tidak nyaman ataupun memadai membuat semangat kerja menurun (Nabawi, 2019). Artinya meskipun lingkungan kerja berada di luar diri manusia tapi sangat besar pengaruhnya terhadap gairah bekerja dan berkarya.

Lingkungan kerja memegang peranan penting dalam kegiatan pendidikan, karena lingkungan kerja adalah tempat sehari-hari guru melakukan aktivitas pekerjaannya (A. R. Saleh \& Utomo, 2018). Dengan lingkungan kerja yang nyaman dan kondusif, maka 
diharapkan akan mampu memberikan kenyamanan dan akan mendorong para guru lebih giat bekerja dan secara otomatis produktivitas yang diharapkan sekolah dapat tercapai (Hasibuan \& Bahri, 2018).

Sekolah adalah lembaga pendidikan yang dimaksudkan untuk menciptakan anak didik yang cerdas, memiliki nilai etika untuk mencapai tujuan nasional melalui proses belajar-mengajar. Pendidikan di sekolah bertujuan menambah nilai-nilai kehidupan bagi anak didik yang bisa saja tidak disampakan dirumah. Anak didik menjadi memiliki akal budi, ilmu pengetahuan dan rasa tanggung jawab baik pada diri maupun lingkungannya. Untuk mencapai tujuan tersebut maka peran unsur pendidikan di sekolah menjadi tolok ukur yang sangat penting yakni guru. Sebab gurulah yang paling banyak berinteraksi dengan anak didik dan secara langsung dilihat dan dicontoh oleh anak didik.

Keberadaan guru dalam proses belajar mengajar jelas menjadi kunci utama dalam menghasilkan anak didik yang berkualitas. Berbagai pembaharuan yang telah dilakukan pemerintah untuk menambah kualitas guru demi mendapatkan guru-guru terbaik yang akan mendidik anak bangsa ke arah yang lebih berkualitas dengan penuh semangat kerja. Semangat kerja adalah situasi ataupun kondisi seseorang melakukan kegiatan secara lebih cepat dan terarah dan memberikan hasil yang optimal disebuah perusahaan. Purwanto (dalam Oktavia 2014:2-3) menyatakan bahwa "semangat kerja adalah reaksi emosional dan mental dari seseorang terhadap pekerjaanya. Semangat kerja mempengaruhi kualitas dan kuantitas pekerjaan seseorang”. Namun untuk menciptakan semangat kerja yang tinggi banyak faktor yang mempengaruhinya.

Yayasan Perguruan Rokita Sari Bangun Purba merupakan salah satu Yayasan Perguruan swasta yang terdiri dari SMP, SMA dan SMK yang terletak di Jln. Perluasan Kota No. 6 Bangun Purba. SMK Swasta Rokita Sari Bangun Purba terletak di jln. Karya No.10 Bangun Purba tepat di belakang Yayasan Perguruan Rokita Sari dan memiliki dua jurusan yaitu SMK Swasta Rokita Sari 1 (Otomotif/TR) dan SMK Swasta Rokita Sari 2 Bisnis Manajemen (BM) yang memiliki jumlah guru sebanyak 35 orang.

Berdasarkan hasil observasi dan wawancara, semangat kerja guru SMK Swasta Rokita Sari Bangun Purba terlihat masih rendah, hal tersebut dilihat dari beberapa guru yang sering tidak hadir, terlambat saat masuk kelas dan bolos saat mengajar. Berbagai hal yang menjadi penyebabnya yaitu komunikasi yang terjadi pada sekolah ini kurang baik 
seperti minimnya interaksi antar guru dan rendahnya koordinasi pembagian tugas dari kepala sekolah kepada guru-guru. Sistem komunikasi yang diterapkan kepala sekolah saat ini tidak mampu merangkul semua guru-guru sehingga kebanyakan guru tidak perduli pada tugas utama yaitu mengajar maupun tugas tambahannya seperti kepanitiaan acaraacara tertentu. Guru banyak yang apatis terhadap berbagai kegiatan sekalipun sudah ditunjuk dalam kepanitiaan. Dari sudut pandang keorganisasian sepatutnya bawahan harus mengikuti arahan dari atasan, kondisi yang terjadi pada sekolah Rokita menunjukkan pentingnya memelihara konomikasi informal bukan hanya mengacu pada atasan dan bawahan. Para guru bisa menyampaikan pendapat ataupun masukannya hanya pada saat pertemuan formal dan pertemuan itupun terlaksana saat ada keperluan mendesak saja dan tidak banyak interaksi antara guru dan kepala sekolah di luar itu.

Faktor lingkungan juga membuat semakin menurunnya semangat guru dalam menjalankan kegiatannya seperti kebisingan di lingkungan sekolah karena berada di tepi jalan raya, pencahayaan yang kurang, fasilitas yang kurang memadai serta bau hewan ternak warga sekitar sekolah. Berbagai kondisi ini membuat penulis tertarik meneliti Pengaruh Komunikasi Dan Lingkungan Kerja Terhadap Semangat Kerja Guru SMK Swasta Rokita Sari Di Yayasan Perguruan Rokita Sari Bangun Purba.

\section{LANDASAN TEORI}

1. Komunikasi

Pada hakikatnya manusia sejak dilahirkan sudah berkomunikasi dengan lingkungannya, dimana kemampuan manusia untuk berinteraksi dengan orang lain baik itu individu ataupun kelompok itulah yang di sebut komunikasi.

Menurut Siswandi (2011: 171) komunikasi adalah sebuah proses mengirim dan menerima info diantara satu pihak yang memiliki kepentingan yang sama sehingga dari proses tersebut didapatkan satu pengertian yang sama. Menurut Sendjaja dalam (Ardial 2018:11) komunikasi adalah sebuah tindakan untuk berbagi informasi, gagasan ataupun pendapat dari setiap partisipan atau komunikator. Tindak komunikasi tersebut dapat dilakukan dalam berbagai konteks.

Komunikasi yang dijalankan dengan efektif dan efisien membantu manajemen dalam menjalankan tugasnya yaitu merencanakan, mengorganisir, melaksanakan, mengarahkan, mengawasi semua kinerja organisasi. Di dalam melakukan komunikasi 
harus diperhatikan berbagai faktor yang akan mempengaruhi semangat kerja secara keseluruhan dan menggunakan komunikasi pada waktu, tempat dan suasana yang tepat agar dapat diperoleh hasil optimal.

Berikut indikator komunikasi menurut Suranto AW (dalam Kristiani 2014:18) agar efektif yaitu :

1. Pemahaman, yaitu kemampuan mengetahui dengan baik dan mampu memodelkan pesan yang disampaikan. Pemberi dan penerima pesan memiliki pengetahuan dan pengertian yang sama.

2. Kesenangan. Maksudnya adalah apabila proses komunikasi itu selain berhasil menyampaikan informasi, juga dapat berlangsung dalam suasana yang menyenangkan ke dua belah pihak.

3. Pengaruh pada sikap. Maksudnya adalah apabila seorang komunikan setelah menerima pesan kemudian sikapnya berubah sesuai dengan makna pesan itu. Dalam berbagai situasi komunikator berusaha mempengaruhi sikap orang lain dan berusaha agar orang lain bersikap positif sesuai keinginan kita.

4. Hubungan yang makin baik. Maksudnya adalah dalam proses komunikasi yang efektif secara tidak sengaja meningkatkan hubungan yang baik. Seperti di sebuah organisasi seringkali terjadi komunikasi dilakukan bukan untuk menyampaikan informasi atau mempengaruhi sikap semata, tetapi untuk membina hubungan baik sesama rekan kerja.

5. Tindakan. Maksudnya adalah baik komunikator dan komunikan memberi respon dalam bentuk perbuatan sesuai dengan isi informasi yang telah mereka komunikasikan.

\section{Lingkungan Kerja}

Lingkungan internal maupun lingkungan eksternal memiliki arti yang sangat penting dalam setiap organisasi. Hal ini disebabkan lingkungan kerja sering mengalami perubahan bisa saja cepat bisa juga dalam waktu yang lama. Tidak ada satupun yang dapat menolah perubahan yang ada karena perubahan akan terjadi cepat atau lambat. Pentingnya memperhatikan lingkungan diarahkan kepada kemampuan organisasi termasuk sekolah dalam mencapai tujuan untuk tetap bersaing dengan sekolah yang lain dalam memberikan pelayanan yang terbaik kepada anak didik. 
Menurut Sedarmayanti (2017:25) lingkungan kerja adalah keseluruhan alat perkakas dan bahan yang dihadapi, lingkungan sekitarnya dimana seseorang bekerja, metode kerjanya, serta pengaturan kerjanya baik sebagai perseorangan maupun sebagai kelompok.

Nitisemito (2014:103) menyebutkan beberapa indikator lingkungan kerja yaitu:

1. Fasilitas. Fasilitas yang memadai akan menunjang semangat dan kegairahan dalam bekerja.

2. Pencahayaan. Diupayakan bagi pihak perusahaan agar memberikan pencahayaan yang cukup di lingkungan kerja.

3. Suhu udara. Suhu udara dapat mengontrol situasi dan suasana dalam bekerja.

4. Tata ruang. Susunan ataupun struktur ruangan akan mempengaruhi suasana karyawan dalam bekerja.

5. Kebisingan. Kebisingan ataupun polusi suara ditempat kerja haruslah dihindari agar karyawan bekerja secara nyaman dan tenteram.

6. Aroma tidak enak di tempat kerja. Diupayakan tidak ada bau yang menggangu guna menciptakan suasana aman dan nyaman saat bekerja.

7. Hubungan karyawan. Adanya sebuah korelasi hubungan antara satu pegawai dengan pegawai lainnya atau atasan dengan bawahan guna mencapai tujuan bersama.

\section{Semangat Kerja}

Nitisemito (2014:427) menyatakan semangat kerja dapat diukur melalui prestasi karyawan ditempat kerja, tanggung jawab terhadap pekerjaannya, disiplin kerja atau kerja sama dengan rekan ataupun atasannya. Berdasarkan teori-teori yang ada, maka dapat diketahui indikator semangat kerja adalah:

1. Absensi atau kehadiran.

2. Kerjasama yakni kemauan melakukan sesuatu demi kepentingan bersama

3. Kepuasan kerja, adalah perasaan ataupun emosional menyenangkan atau tidak menyenangkan atas hasil kerja

4. Disiplin, adalah suatu tingkah laku terhadap peraturan yang tertulis maupun budaya yang ada pada organisasi. 
274 | Jurnal Pendidikan dan Kewirausahaan Vol. 9 No. 12021

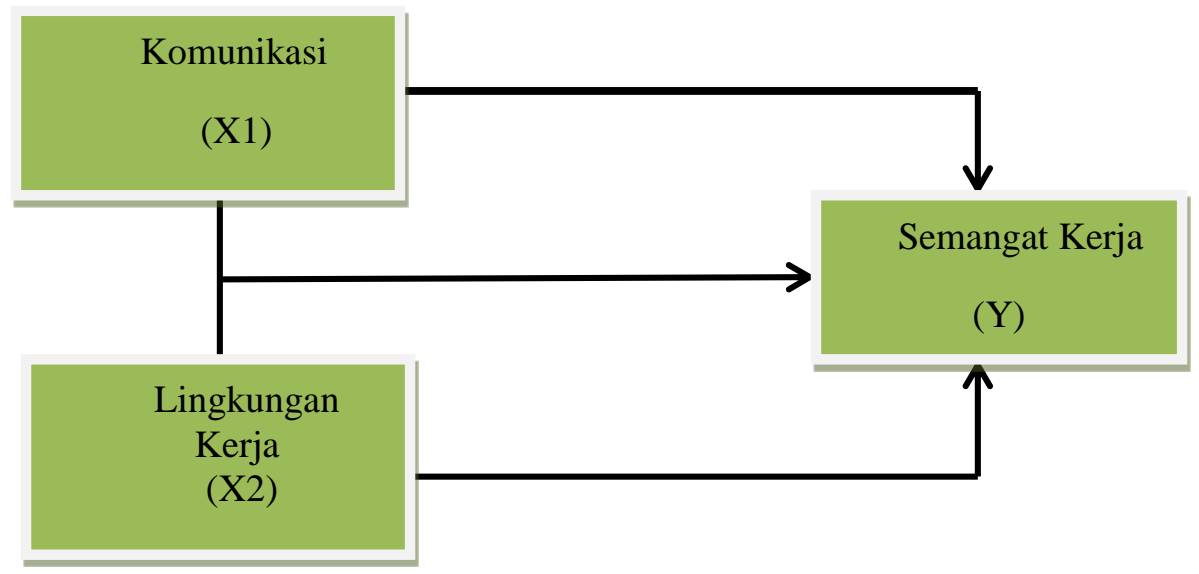

Gambar 1. Kerangka Konseptual

Hipotesis:

Dari kerangka konseptual di atas, penulis membuat hipotesis penelitian yakni:

1. Komunikasi berpengaruh signifikan terhadap semangat kerja guru SMK Swasta Rokita Sari di Yayasan Perguruan Rokita Sari Bangun Purba

2. Pengaruh Lingkungan kerja berpengaruh signifikan terhadap semangat kerja guru SMK Swasta Rokita Sari di Yayasan Perguruan Rokita Sari Bangun Purba.

3. Pengaruh Komunikasi dan lingkungan kerja secara simultan berpengaruh signifikan terhadap semangat kerja guru SMK Swasta Rokita Sari Bangun Purba.

\section{METODE PENELITIAN}

Penelitian ini merupakan penelitian deskriptif statistik. Populasi (wilayah penelitian yang ditetapkan peneliti dalam penelitian ini, adalah seluruh guru SMK Swasta Rokita Sari di Yayasan Perguruan Rokita Sari Bangun Purba yang berjumlah 35 orang dimana seluruh populasi dijadikan sampel dalam penelitian (Sugiyono, 2016). Penelitian ini didesain menggunakan suvei dengan memberikan kuesioner tertutup kepada para guru dengan menggunakan skala likert. Variabel komunikasi menggunakan pertanyaan tentang pemahaman, kesenangan, pengaruh pada sikap, hubungan yang makin baik. Pertanyaan untuk variabel lingkungan kerja suhu udara, hubungan kerja, kebisingan, bau ditempat kerja. Absensi, kerja sama, kepuasan kerja dan kedisiplinan untuk variabel adalah pertanyaan untuk variabel semangat kerja. Analisis data menggunakan multiple regression analysis model (model analisis berganda) baik secara parsial maupun simultan. 
275 | Jurnal Pendidikan dan Kewirausahaan Vol. 9 No. 12021

\section{HASIL DAN PEMBAHASAN}

Hasil survei lapangan mengenai karakteristik responden disajikan sebagai berikut.

\section{Identitas Responden}

Berikut hasil pengumpulan data disajikan menurut jenis kelamin, usia dan lama bekerja guru-guru di SMK Swasta Rokita.

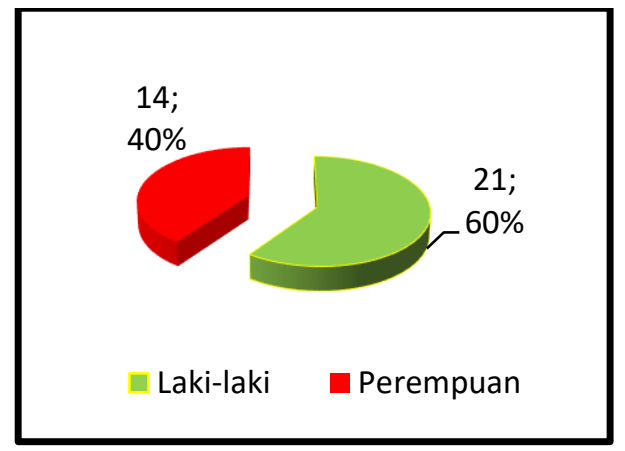

Gambar 2. Jenis Kelamin Responden

Guru di SMK Swasta Rokita dengan jenis kelamin laki-laki sebanyak 21 orang (60\%) dan perempuan sebanyak 14 orang (40\%). Dari jumlah responden mayoritas lakilaki menunjukkan perlu adanya komunikasi yang baik karena pada umumnya laki-laki akan bekerja dengan maksimal dengan petunjuk dan arahan yang benar.

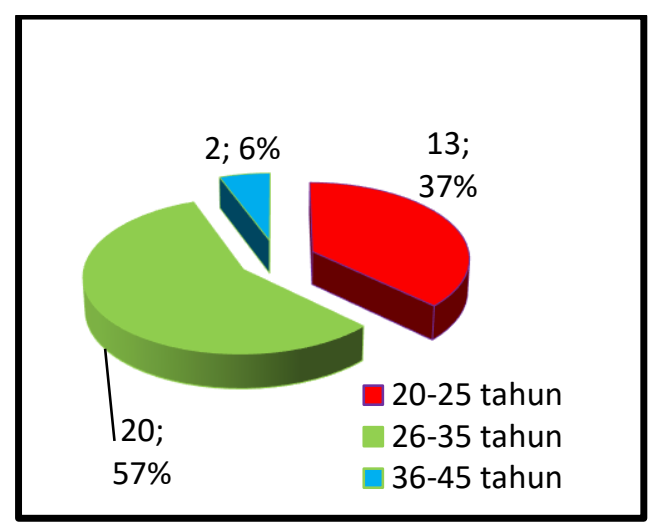

Gambar 3. Usia Responden

Usia mempengaruhi kualitas semangat kerja, guru dengan usia masih muda dan produktif cenderung memiliki semangat kerja yang tinggi. Apabila dilihat gambar di atas guru-guru mayoritas memiliki semangat kerja yang baik karena responden paling banyak berusia produktif yaitu usia 26-35 tahun yakni 20 orang (57\%). 


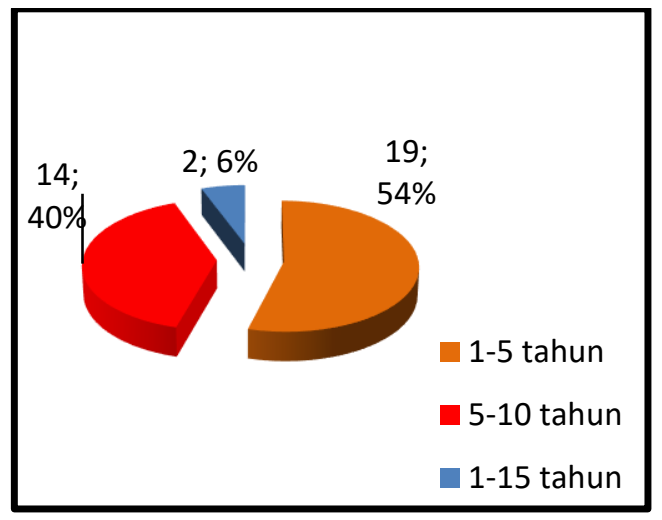

Gambar 4. Lama Kerja Responden

Berdasarkan gambar dapat dilihat lama bekerja reponden paling banyak berada pada rentang 1-5 tahun atau 54\%. Kondisi dengan mayoritas Guru dengan lama kerja seperti ini memerlukan sistem komunikasi formal maupun informal di sekolah baik dari kepala sekolah kepada guru-guru dan sesama rekan guru harus baik agar guru-guru yang masih muda dan belum banyak pengalaman semakin tahu apa yang harus dikerjakan.

\section{Uji Kualitas Data}

\section{a) Uji Validitas}

Uji Validitas ditunjukkan oleh nilai yang didapat dari pengolahan data kuesioner yakni melihat perbandingan nilai $r$ hitung dan rtabel. Jumlah sampel 35 orang dan tingkat kepercayaan $95 \%$ besar $r$ hitung 0.282 . Sesuai dengan ketentuan $r_{\text {hitung }}>r_{\text {tabel }}$ maka kuesioner dianggap valid, apabila $r_{h i t u n g}<r_{\text {tabel }}$ butir pertanyaan kuesioner dinyatakan tidak valid. Berdasarkan hasil uji validitas semua butir pertanyaan untuk variabel komunikasi (x1) dan lingkungan kerja (x2) diperoleh nilai $\mathrm{r}_{\text {hitung }}$ lebih besar dari 0,282 maka dinyatakan valid. Sedangkan untnuk variabel $Y$ terdapat 1 butir pertanyaan yang tidak valid (tidak dimasukkan untuk penelitian selanjutnya).

\section{b) Uji Realibilitas}

Hasil uji reliabilitas menunjukan bahwa semua instrument peneltian dinyatakan reliabel atau layak untuk dilanjutkan, karena semua instrument penelitian bernilai diatas 0,60

\section{Asumsi Klasik}

Hasil uji asumsi klasik penelitian ini sebagai berikut : 


\section{a. Uji Normalitas}

Hasil uji normalitas dengan melihat Normal Probability Plot, gambar dibawah menunjukkan bahwa data yang diuji bersifat normal dikarenakan penyebaran data (titik) pada sumbu mendekati diagonal grafik.

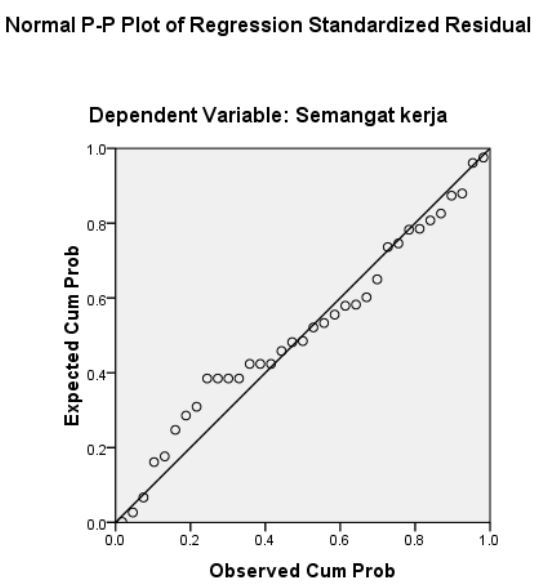

Sumber Hasil Peneltian 2021

\section{Gambar 5. P-Plot Normalitas}

\section{b. Uji Multikolinearitas}

Sesuai dengan Ghozali, I. (2013) hasil uji multikolinieritas berdasarkan hasil pengolahan data diperoleh nilai tolerance bernilai lebih besar dari 0.10 yakni 0.756 dengan nilai VIF sebesar 1.309 artinya tidak terjadi multikolinieritas.

\section{c. Uji Heteroskedastisitas}

Hasil pengolahan data diperoleh titik-titik tersebar dengan acak dan tidak ada membentuk pola yang teratur. Titik-titik yang ada menyebar pada atas sumbu Y dan bawah angka 0 seperti yang ditampilkan dibawah ini. Artinya tidak terdapat heterokedastisitas pada data penelitian ini. 
Scatterplot

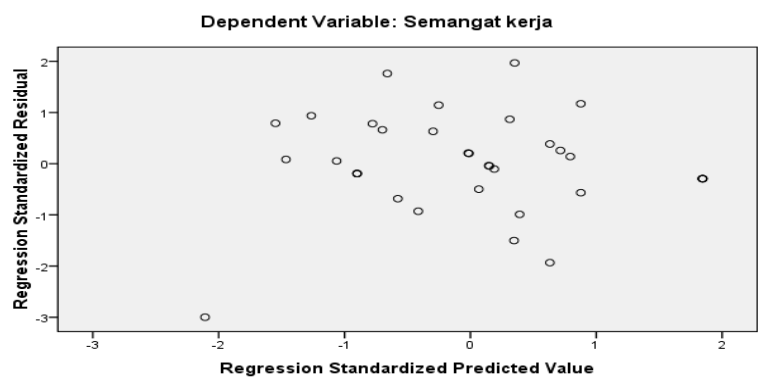

Sumber Hasil Peneltiian 2020

Gambar 6. Scatterplot

\section{Uji Regresi Berganda}

Tabel 1. Hasil regresi linier berganda disajikan pada tabel di bawah ini.

\section{Coefficients $^{\mathrm{a}}$}

\begin{tabular}{|c|c|c|c|c|c|c|}
\hline \multirow{3}{*}{\multicolumn{2}{|c|}{ Model }} & \multirow{2}{*}{\multicolumn{2}{|c|}{ Unstandardized Coefficients }} & \multirow{2}{*}{$\begin{array}{l}\text { Standardized } \\
\text { Coefficients }\end{array}$} & \multirow[b]{3}{*}{$\mathrm{t}$} & \multirow[b]{3}{*}{ Sig. } \\
\hline & & & & & & \\
\hline & & B & Std. Error & Beta & & \\
\hline \multirow[t]{3}{*}{1} & (Constant) & -.362 & 3.541 & & -.102 & .919 \\
\hline & Komunikasi & .526 & .101 & .568 & 5.207 & .000 \\
\hline & $\begin{array}{l}\text { Lingkungan } \\
\text { kerja }\end{array}$ & .424 & .115 & .404 & 3.699 & .001 \\
\hline
\end{tabular}

a. Dependent Variable:

Semangat kerja

\section{Sumber Hasil Penelitian 2021}

Hasil regresinya dalam bentuk persamaan yaitu:

$$
\mathrm{Y}=-0.362+0.526+0.424+\mathrm{e}
$$

Nilai konstanta sebesar - 0.362 hal ini menunjukkan dalam keadaan konstan (ceteris paribus) variabel komunikasi (X1) dan lingkungan kerja (X2) maka semangat kerja guru SMK Swasta Rokita Sari sebesar - 0.362. Artinya tanpa komunikasi yang baik dan lingkungan kerja maka tidak ada semangat kerja guru atau bahkan menurun sebesar 0,362 satuan. 
Angka koefisien regresi variabel komunikasi 0.526 artinya apabila dilakukan perbaikan komunikasi sebesar $1 \%$ (cateris paribus) maka akan meningkatkan semangat kerja guru pada SMK Swasta Rokita Sari yakni 5.26\%.

Angka koefisien regresi lingkungan kerja adalah 0.424 hal ini berarti jika lingkungan kerja diperbaiki sebesar 1\% (Cateris Paribus) maka akan meningkatkan semangat kerja guru SMK Swasta Rokita Sari sebesar 4.24\%.

\section{Pengujian Hipotesis}

a. Uji t

Hasil uji t yang ditunjukkan pada tabel 1 untuk variabel komunikasi diperoleh taraf signifikan yang bernilai $0.000<0.05$. Hasil penelitian ini menunjukkan bahwa komunikasi berpengaruh signifikan terhadap semangat kerja guru SMK Swasta Rokita Sari.

Demikian juga untuk variabel lingkungan kerja diperoleh nilai sig $0.001<0.05$ artinya lingkungan kerja berpengaruh signifikan terhadap semangat kerja guru SMK Swasta Rokita Sari.

b. Uji F

Tabel 19. Uji F

\section{ANOVA}

\begin{tabular}{llcllll}
\hline Model & Sum of Squares & Df & Mean Square & F & Sig. \\
\hline 1 & Regression & 232.203 & 2 & 116.101 & 38.968 & $.000^{\mathrm{a}}$ \\
\cline { 2 - 4 } & 95.340 & 32 & 2.979 & & \\
\hline Residual & 327.543 & 34 & & & \\
\hline Total & & & & & \\
\hline
\end{tabular}

a. Predictors: (Constant), Lingkungan kerja, Komunikasi

b. Dependent Variable:Semangat kerja

Sumber Hasil Peneltian 2021

Berdasarkan tabel di atas nilai signifikan yang bernilai 0,000 sedang taraf yang di tentukan adalah 0.05 , dalam hal ini $(0.000<0.05)$ artinya H0 ditolak. Maka dapat 
disimpulkan bahwa variabel komunikasi, dan lingkungan kerja secara simultan berpengaruh secara signifikan terhadap semangat kerja guru SMK Swasta Rokita Sari.

\section{Koefisien Determinasi}

Tabel 20. Model Summary

\begin{tabular}{lllll}
\hline & & & Ad justed R & $\begin{array}{c}\text { Std. Error } \\
\text { Model }\end{array}$ \\
\hline 1 & $.842^{\mathrm{a}}$ & .709 & .691 & 1.72609 \\
\hline
\end{tabular}

a. Predictors: (Constant), Lingkungan kerja, Komunikasi kerja Sumber Hasil Peneltian 2021

Nilai $R$ Square dari hasil pengolahan data diperoleh sebesar 0.709 berarti $70.9 \%$ variabel komunikasi, dan lingkungan kerja mampu menjelaskan pengaruhnya terhadap semangat kerja guru SMK Swasta Rokita Sari, sedangkan sisanya 29.1\% adalah hal lain yang tidak diteliti pada penelitian ini.

\section{Pembahasan}

Hasil penelitian ini sejalan dengan penelitian sebelumnya yang dilakukan oleh Azira (2018) yaitu komunikasi memberi pengaruh signifikan terhadap semangat kerja. Artinya komunikasi tidak dapat diabaikan pada setia manajemen organisasi terlebih organisasi sekolah dimana sekolah mampu memberikan pendidikan yang terbaik dan mampu bersaing dengan sekolah lain. Hasil penelitian Agung \& Inten (2018) juga menyatakan bahwa komunikasi dan lingkungan kerja berpengaruh terhadap semangat kerja. Komunikasi yang dimaksud dapat dilakukan dengan melalui acara formal seperti rapat dan komunikasi non formal dengan tetap memperhatikan berbagai faktor ketepatan waktu, tempat dan suasana untuk mencapai hasil yang diharapkan. Komunikasi yang efektif dan efisien serta tidak membosankan tentu saja akan mendorong kepala sekolah dan guru SMK Swasta Rokita Sari saling memberikan respon terhadap tujuan yang diharapkan. Komunikasi yang baik akan meningkatkan semangat kerja secata signifikan karena guru merasa dihargai, seperti diketahui bahwa secara psikologis orang yang merasa dihargai akan memberikan kualitas terbaiknya melakukan sesuatu dalam lingkungannya. 
Demikian juga lingkungan kerja berpengaruh signfikan terhadap semangat kerja dan hasil ini sejalan dengan penelitian sebelumnya yang dilakukan oleh Zayani et al., (2020) Teori Kurt Lewis yang merumuskan $\mathrm{P}=\mathrm{f}$ (K.L) menunjukkan bahwa perilaku merupakan fungsi dari karakteristik pribadi dan lingkungan. Penelitian Abdi (2018) juga menyatakan promosi jabatan dan lingkungan kerja berpengaruh positif dan signifikan terhadap semangat kerja.

Dengan demikian maka SMK Swasta Rokita Sari perlu memperhatikan lingkungan sekolah karena mempengaruhi semangat kerja guru. Semakin berkualitas kondisi lingkungan fisik dan non fisik serta lingkungan internal dan eksternal yang mengitari guru maka akan semakin baik pula semangat kerja guru-guru.

Lingkungan memberikan efek yang luar biasa bagi banyak hal selain memberi semangat pada guru-guru juga memberikan nilai lebih bagi minat anak-anak didik yang bersekolah atau mau bersekolah di SMK Swasta Rokita Sari. Dengan demikian lingkungan kerja yang baik akan memenangkan SMK Swasta Rokita Sari dalam persaingan mendapatkan jumlah anak didik dengan sekolah dengan jurusan yang sama. Begitu besarnya lingkungan mempengaruhi manajemen sekolah maka Yayasan melalui kepala sekolah harus mampu mengelola kebijakan untuk menghadapi perubahan yang ada maupun menciptakan perubahan pada lingkungan yang menjemukan. Tidak ada satu cara yang mutlak untuk melaksanakan analisis lingkungan kerja Sekolah SMK Swasta Rokita Sari, maka Yayasan dan Kepala Sekolah harus mampu menemukan dan mengembangkan sendiri cara yang tepat yang relevan dengan tujuan yang mereka harapkan.

\section{SIMPULAN}

Komunikasi berpengaruh positif dan signifikan terhadap semangat kerja hal ini ditunjukkan dengan hasil nilai sig yang bernilai $0.000<0.05$. Lingkungan kerja berpengaruh positif dan signfikan terhadap semangat kerja hal ini dilihat dari nilai signifikansi yang yang diperoleh bernilai $0.001<0.05$. Secara simultan komunikasi dan lingkungan kerja berpengaruh positif dan signifikan terhadap semangat kerja pada guru SMK Swasta Rokita Sari, terlihat dari terlihat dari nilai signifikansi $0.000<0.05$. 


\section{Saran}

1. Supaya terjadi komunikasi yang lancar para guru SMK Swasta Rokita Sari, para guru harus lebih interaktif dengan sesama guru ataupun murid sehingga akan tercipta komunikasi dua arah yang lancar baik antar sesama guru, guru ke murid ataupun guru ke kepala sekolah.

2. Dari angket yang sudah disebar lingkungan kerja yang diinginkan para guru adalah lingkungan kerja yang hening tanpa kebisingan yang berlebihan dan juga meninginkan fasilitas yang memadai sehingga transfer ilmu antara guru dan murid bisa terjadi dengan lancar. Maka manajemen sekolah harus mengambil beberapa kebijakan yang dapat mengurangi kebisingan.

3. Semangat kerja dari guru-guru SMK Swasta Rokita Sari bisa ditingkatkan dengan memberikan kebutuhan mengajar yang lebih lengkap dan sering mengadakan acara atau kegiatan diluar sekolah.

4. Agar pihak yayasan menyediakan kotak suara agar para guru dapat mengaspirasikan atau menyampaikan kritik dan saran selama berada di lingkungan disekolah.

\section{DAFTAR RUJUKAN}

Abdi, S. (2018). Pengaruh Promosi Jabatan Dan Lingkungan Kerja Terhadap Semangat Kerja Pegawai Di Lingkungan Universitas Pembangunan Pancabudi Medan. Jurnal Akuntansi Bisnis Dan Publik, 8(2), 191-203.

Adha, R. N., Qomariah, N., \& Hafidzi, A. H. (2019). Pengaruh Motivasi Kerja , Lingkungan Kerja , Budaya Kerja Terhadap Kinerja Karyawan Dinas Sosial Kabupaten Jember. 4(1), 47-62.

Agung, A., \& Inten, I. (2018). Terhadap Semangat Kerja Karyawan Pada Pt . Bali Bimasakti Denpasar. Jurnal Pendidikan, 2(1).

Hasibuan, S. M., \& Bahri, S. (2018). Pengaruh Kepemimpinan, Lingkungan Kerja dan Motivasi Kerja Terhadap Kinerja. 1(1), 71-80.

Nabawi, R. (2019). Pengaruh Lingkungan Kerja, Kepuasan Kerja dan Beban Kerja Terhadap Kinerja Pegawai. Maneggio: Jurnal Ilmiah Magister Manajemen, 2(2), 170-183. https://doi.org/10.30596/maneggio.v2i2.3667

Ningrum, M. E. (2013). Peranan Komunikasi Internal Di Lingkungan Kerja. Indept, 3(1), 
283 | Jurnal Pendidikan dan Kewirausahaan Vol. 9 No. 12021

$25-30$.

Pratama, A. A. N., \& Wardani, A. (2018). Pengaruh Kemampuan Kerja dan Semangat Kerja Terhadap Kinerja Karyawan Melalui Kepuasan Kerja (Studi Kasus Bank Syariah Mandiri Kantor Cabang Kendal). Muqtasid: Jurnal Ekonomi Dan Perbankan Syariah, 8(2), 119. https://doi.org/10.18326/muqtasid.v8i2.119-129

Saleh, A. R., \& Utomo, H. (2018). Pengaruh Disiplin Kerja, Motivasi Kerja, Etos Kerja Dan Lingkungan Kerja Terhadap Produktivitas Kerja Karyawan Bagian Produksi Di Pt. Inko Java Semarang. Among Makarti, 11(1), 28-50. https://doi.org/10.52353/ama.v11i1.160

Saleh, R., Suib, M., \& Sindju, H. B. (2016). Peran Kepala Sekolah Sebagai Administrator Dalam Meningkatkan Efektivitas Layanan Administrasi di SMP Santu Petrus Pontianak. Jurnal Pendidikan Dan Pembelajaran Khatulistiwa, 5(2), 1-17. https://jurnal.untan.ac.id/index.php/jpdpb/article/view/13982

Siregar, M. (2019). Hubungan Antara Pemenuhan Kebutuhan Psikologis Dengan Semangat Kerja Pada Karyawan Bank Mandiri Cabang Balige. Jurnal Diversita, 5(1), 33-36. https://doi.org/10.31289/diversita.v5i1.2471

Sugiyono. (2016). Metode Penelitian kuantitatif, kualitatif, dan R\&D (Alabeta (ed.)). Alfabeta.

Zayani, N. A., Rozi, F., \& Muhsin, M. (2020). Pengaruh Kompetensi, Kenyamanan Lingkungan, Komunikasi Interpersonal, dan Semangat Kerja Terhadap Kualitas Pelayanan Administrasi Terpadu Bidang Non Perizinan. Economic Education Analysis Journal, 9(3), 18-23. https://doi.org/10.15294/eeaj.v9i3.42110 